Bond University

Research Repository

\title{
Nutrition Strategies for Triathlon
}

Burke, Louise M.; Cox, Gregory Roland

Published in:

Triathlon Medicine

DOI:

10.1007\%2F978-3-030-22357-1_17

Licence:

Other

Link to output in Bond University research repository.

Recommended citation(APA):

Burke, L. M., \& Cox, G. R. (2020). Nutrition Strategies for Triathlon. In S. Migliorini (Ed.), Triathlon Medicine (pp. 261-287). Springer. https://doi.org/10.1007\%2F978-3-030-22357-1_17

\section{General rights}

Copyright and moral rights for the publications made accessible in the public portal are retained by the authors and/or other copyright owners and it is a condition of accessing publications that users recognise and abide by the legal requirements associated with these rights.

For more information, or if you believe that this document breaches copyright, please contact the Bond University research repository coordinator. 


\section{Nutrition strategies for triathlon}

Louise M. Burke $\mathrm{e}^{1,2}$ and Gregory R. Cox ${ }^{3,4}$

${ }^{1}$ Australian Institute of Sport, Canberra, Australia; louise.burke@ausport.gov.au

${ }^{2}$ Mary MacKillop Institute for Health Research, Australian Catholic University, Melbourne, Australia

${ }^{3}$ Bond University, Faculty of Health Sciences and Medicine, Gold Coast, Australia

${ }^{4}$ Triathlon Australia, Gold Coast, Australia: gcox@bond.edu.au

\section{Corresponding author:}

Louise Burke

Australian Institute for Sport

PO Box 176

Belconnen, ACT, 2616

Australia

Email: Louise.burke@ausport.gov.au

Phone: +61 (4) 422635869 


\begin{abstract}
Contemporary sports nutrition guidelines recommend that each athlete develop a personalised, periodised and practical approach to eating that allows him or her to train hard, recover and adapt optimally, stay free of illness and injury and compete at their best at peak races. Competitive triathletes undertake a heavy training program to prepare for three different sports, while undertaking races varying in duration from 20 minutes to 10 hours. The everyday diet should be adequate in energy availability, provide $\mathrm{CHO}$ in varying amounts and timing around workouts according to the benefits of training with low or high $\mathrm{CHO}$ availability, and spread high-quality protein over the day to maximise the adaptive response to each session. Race nutrition requires a targeted and well-practiced plan that maintains fuel and hydration goals over the duration of the specific event, according to the opportunities provided by the race and other challenges, such as a hot environment. Supplements and sports foods can make a small contribution to a sports nutrition plan, when medical supplements are used under supervision to prevent/treat nutrient deficiencies (e.g. iron or Vitamin D) or when sports foods provide a convenient source of nutrients when it is impractical to eat whole foods. Finally, a few evidence-based performance supplements may contribute to optimal race performance when used according to best practice protocols to suit the triathlete's goals and individual responsiveness.
\end{abstract}

Keywords: diet, Ironman, carbohydrate loading, sports foods, supplements, train low 


\section{Introduction}

Over the past 60 years, sports nutrition has evolved from a collection of anecdotes about the dietary strategies of successful athletes, supplemented by laboratory-based studies typically involving recreational competitors, into a credible science underpinning the health and performance of all athletes [1]. The continual updating of consensus statements and position stands by expert groups on global areas of sports nutrition [2] as well as individual topics within its umbrella [3-5], illustrates the pace with which new information is evolving. The specific nutrition needs and practices of importance to athletes, even within a single sport, are diverse. However, all athletes share some common goals; to train as hard as possible with optimal adaptation and recovery, to retain healthy and injury-free, to achieve a physique that is suited to their event, and to perform at their best on the day(s) of peak competitions. This chapter will present a summary of eight key themes in contemporary sports nutrition with an examination of their relevance and implementation within triathlon.

\section{Theme 1. Nutrition goals and requirements are neither static nor universal}

Early position statements and reviews on sports nutrition provided quantitative recommendations for nutrient targets for all athletes [6], focusing on single issues (e.g. daily replacement of glycogen) and apparently addressing all training phases and sub-populations of athletes with the same advice. These recommendations have gradually evolved to recognise that macronutrient targets should not be set in absolute amounts or as ratios of energy intake; instead, guidelines should encompass the differences in body sizes, training loads and energy goals across athlete populations [7, 8]. More recently, however, there has been specific attention to the need for each athlete to develop a personalised, periodised and practical eating plan that supports their unique and changing needs. Although more detail around these principles will be provided below, it is important to highlight a key insight that underpins these features. 
Contemporary sports nutrition guidelines embrace the philosophy of periodization that governs the athlete's annual training plans [9]. Although various models of training periodization exist, the fundamental theory is that exercise sessions should be strategically manipulated (mode, frequency, intensity and duration) within a sequence of cycles to gradually achieve the attributes (e.g. physical, biomechanical, physiological, neuromuscular, psychological) needed for success at chosen competitions. Periodized nutrition involves the organization of nutrient intakes and dietary strategies around each session, microcycle (e.g. week), mesocycle (e.g. month) and macrocycle (e.g. yearly plan) of training to help address the individual athlete's gaps to achieving these event-specific attributes. The diversity and complexity of the different attributes for success, even within a single sport, means that many aspects of nutrition may change or differ between athletes.

\section{Application to triathlon}

Although triathlon is considered an endurance sport, it encompasses a range of events from $20 \mathrm{~min}$ to $8 \mathrm{~h}+$ in duration, with different requirements for success [10]. Specific preparation for each race format will require different training programs, protocols and goals, leading to overall differences between event specialists or changes across the season in the same triathlete as they prepare for different races. Even within a triathlete's training program, daily or weekly fluctuations in training load and goals should be matched by changes in energy and nutrient intake. Furthermore, specialized nutrition strategies that optimize performance or adaptation, or mimic race day practices should be integrated around key training sessions or training phases. Table 1 provides some examples of nutrients and nutritional strategies that may be periodized within different programs commonly undertaken by triathletes. The deliberate implementation of this targeted and individualised approach to sports nutrition is a highly specialized task that should involve the input of the triathlete, coach, sports scientists and sports nutrition expert, with continual fine-tuning according to feedback and experience. 
Menu plans and nutrition strategies should also take into account an individual's food preferences, cultural eating practices and special dietary needs including food restrictions and intolerances, as well as food availability in the athlete's environment which is ever changing with the global nature of triathlon racing.

\section{Theme 2. Energy availability sets an important foundation for health and performance}

\section{success}

Energy intake is the foundation of an athlete's diet since it supports optimal body function, determines the capacity for intake of macronutrient and micronutrients, and assists in manipulating body composition. Conventionally, nutritionists have focused on energy balance and how each side of the energy equation (dietary energy intake vs total daily energy expenditure) can be manipulated to store or utilize body fat and protein and thus achieve desirable changes in physique (e.g. gain in muscle mass, loss of body mass [BM]/body fat). However, energy availability (EA) is a newer concept in sports nutrition which examines the energy that is left to address the body's many non-exercise needs once the energy cost of training and competition is removed [11]. EA is defined operationally as dietary intake minus exercise energy expenditure, normalized to the body's fat free mass [FFM) which represents the most metabolically active tissues:

$\mathrm{EA}=[$ Energy intake $=$ Exercise Energy Expenditure $) / \mathrm{FFM}[11]$

It is self-evident that the energy that is committed to an athlete's exercise program is not available for other functions. Importantly, if a mismatch between energy intake and exercise load leads to a reduction in EA, the body adapts to conserve energy by reducing expenditure on non-exercise functions. There is sophisticated laboratory evidence that when EA is decreased from a "healthy" level ( $45 \mathrm{kcal} / \mathrm{kg}$ FFM or $189 \mathrm{~kJ} / \mathrm{kg}$ FFM) below a threshold (typically set at $\sim 30 \mathrm{kcal} / 125 \mathrm{~kJ} / \mathrm{kg}$ FFM), many hormonal and metabolic processes are impaired by such energy conservation [12]. Low Energy Availability (LEA) underpins the 
problems of impaired bone health and menstrual function identified in the Female Athlete Triad syndrome [13], but new insights over the last decade have identified its occurrence in male athletes and its impact on a range of other body systems and performance factors [14]. Indeed, the concept of Relative Energy Deficiency in Sport (RED-S) was developed to address this expanded concern, including the sequelae of functional hypothalamic amenorrhea (females), reduced testosterone levels and libido (males), poor bone health, increased risk of illness and injuries, gastrointestinal disturbances and cardiovascular disease, and impairments of haematological status, training capacity and performance $[5,14]$. The main causes of LEA are disordered eating, misguided weight loss programs and inadvertent failure to recognize or address a high energy expenditure associated with training/competition [11]. Although general risk factors for these issues can be identified in various sports (e.g. weight sensitive and weight category sports) or sporting scenarios (e.g. sudden increase in training load, change in food environment), it appears that other sport- and culture-specific characteristics contribute both to the development of LEA and the manifestation of its effects on health and performance [14]. Programs that promote prevention and screening/early intervention are important to prevent long-term secondary health consequences. The primary treatment is to increase energy availability and often requires a team approach including a sports physician, sports dietitian, physiologist, and psychologist.

\section{Application to triathlon}

Triathlon involves a number of risk factors for the development of LEA as well as the progression of impaired body function into tangible problems around health and performance. Given the long gestation from junior ranks to elite race winner (typically late 20's), a significant loss of time to injury and illness will delay, and in many instances prevent, a junior triathlete from developing into an elite level performer. The heavy training loads required to master three different sports, and the preparation for the longer events within 
triathlon, often tally 20-30 hours per week. Both the energy expenditure associated with such a program and the significant number of hours committed to training and recovery activities create a challenge in meeting energy needs within the available opportunities. Athletes should be vigilant to capture opportunities before, during and after training to replenish energy needs, and to manipulate food and fluid selections to reflect training schedules. The desire to be as light and lean, often misguided in relation to both the goals and time frame of achieving/maintaining them, adds a separate contribution to the development of LEA and RED-S, which is discussed below.

\section{Theme 3. The achievement of the body composition associated with optimal performance is challenging and requires a long-term plan}

Various attributes of physique (body size, shape and composition) are considered to contribute to success in various sports. The assessment and manipulation of some features (e.g. BM, body fat, lean mass) may assist in the progression of an athletic career. High performance endurance athletes are typically light and lean as a result of the genetic factors that have predisposed them to being successful in their sport as well as the modifying effects of training and diet. However, the specific muscular strength and power required in many sports may require targeted gains in lean mass. Body mass and composition can be assessed via a number of techniques, with surface anthropometry [e.g. measurements of girths, breadths and subcutaneous (skinfold) fat) being a popular field technique and Dual X-Ray Absorptiometry (DXA) being a technological tool of increasing popularity [15, 16]. Both techniques can provide valuable information when they are used, according to standardized techniques by trained personnel, to track changes over time in the same athletes. The interpretation of these assessments should always account for the precision of the technique, while goals around manipulating body fat/lean mass should consider what is optimal for an individual athlete's long-term health and performance goals rather than rigid prescriptions of 
an "ideal" formula for a specific event. Effective strategies for loss of body mass/fat should achieve an energy deficit that avoids unnecessary restriction of EA and takes advantage of the meal satiety and lean mass preservation associated with a higher protein intake [17]. Gains in lean mass are achieved by an appropriate training program, supported by the spread and total intake of energy and protein [18]. Unfortunately, many athletes set unreasonable goals and methods to achieve more rapid results, leading to compromises of health and performance.

A more successful approach to management of body composition is to achieve periodization over the yearly training plan, using the experience gained over an athletic career to permit gradual refinement of ranges that are best suited to the individual athlete. Indeed, this periodized approach was well illustrated in a recently published 9-year case history of a female Olympic middle-distance runner [19]. During the general preparation phase of each season, optimal energy availability was prioritized, with the athlete being $\sim 2-4 \%$ over her ideal "race weight" and body fat levels. Optimization of body composition prior to each racing season included the implementation of an individualized energy deficit over a specific timeframe, using various metrics (BM, performance, and hunger) to guide the process. This approach targeted peak performance at identified times, while minimizing injury risk and maximizing training adaptation and long-term athlete health through management of energy availability.

\section{Application to triathlon}

Junior development and age-group triathletes are often misguided in their desire to achieve rapid shifts in 'leanness' and enthusiastically employ strategies that target reductions in fat mass without considering the larger implications around diet quality and overall health.

Reducing energy intake to drive a reduction in fat mass, will likely reduce EA with the risk of contributing to health and performance concerns associated with RED-S [4]. Restricted energy intakes or extreme diets may also lead to a sub-optimal intake of nutrients needed for 
health and adaptation. The disadvantages of unsound weight/fat loss strategies may manifest in terms of increased prevalence of illness an injury, and as an inability to train consistently or to gain the expected adaptations and performance improvements. The concept of improving performance through the optimisation of the "power to weight" ratio is well known in triathlon, but many triathletes fail to realise that a gain in lean mass can also assist with this goal and is a hallmark of developing into an elite performer. In essence, triathletes should adopt eating strategies that support daily training outcomes as well as promote increases in protein synthesis to achieve favourable body composition changes that align with world class performances.

\section{Theme 4. Guidelines for nutrition need to consider training load, body size and timing of intake}

Although recommended dietary intakes for the general population are typically provided as simplistic (absolute) nutrient targets or ranges, the specific needs of athletes merit greater consideration, particularly to account for the variability imposed by their exercise demands and the potential importance of the timing of nutrient intake in relation to an exercise session. The complexity of contemporary guidelines for the carbohydrate $(\mathrm{CHO})$ and protein intakes of endurance athletes is well illustrated by their application to the needs of triathlon $\mathrm{CHO}$ is an important dietary nutrient since body stores are relatively limited and can be acutely manipulated by daily intake and even a single training session within a triathlete's program [20]. CHO is a key fuel for the brain and central nervous system and provides a versatile muscle substrate because it can support exercise over the large range of intensities seen in a triathlon due to its utilization by both anaerobic and oxidative pathways [20]. There is robust evidence that the performance of prolonged sustained or intermittent high-intensity exercise is enhanced by strategies that maintain high $\mathrm{CHO}$ availability, defined as matching endogenous (e.g. muscle glycogen) and exogenous (e.g. CHO consumed during exercise) 
sources to the fuel demands of exercise [21, 22]. Meanwhile, depletion of these stores is associated with fatigue in the form of reduced work rates, impaired skill and concentration, and increased perception of effort [20-22]. These findings underpin various race nutrition strategies, discussed subsequently, that supply carbohydrate before, during, and in the recovery between events to enhance carbohydrate availability, but should also be extended to training scenarios where high quality outputs or race simulation is desired.

Guidelines for daily $\mathrm{CHO}$ intake now target the variable fuel costs of training [8] as well as the importance of high $\mathrm{CHO}$ availability for performance and support for other body systems, such as immune [23] and, potentially, bone [24] health. Although the actual substrate cost of typical training sessions undertaken by endurance athletes is (surprisingly) poorly characterized [25], some general ranges of $\mathrm{CHO}$ intake are suggested according to parameters that account for the workload [e.g. intensity, duration of the session) and the triathlete's body mass (as a proxy for the size of the working muscle). Table 1 includes a summary of guidelines for various scenarios in which there may be benefits to achieving high $\mathrm{CHO}$ availability, providing daily targets which can be fine-tuned according to individual experience and noting that the timing of intake of $\mathrm{CHO}$ in relation to the exercise session plays a role in manipulating $\mathrm{CHO}$ availability $[8,21]$. Integration of these guidelines into a race plan is summarised in Table 2 and discussed in more detail within a subsequent theme. It is important also to note that many training scenarios do not require promotion of $\mathrm{CHO}$ availability or intake, allowing the triathlete to manipulate their food choices to meet other goals. Furthermore, as discussed subsequently, benefits from deliberate strategies to undertake training sessions with low $\mathrm{CHO}$ availability may also be possible. Thus, $\mathrm{CHO}$ intakes may vary significantly between athletes, and from day to day in the same athlete [21]. Despite earlier debate, contemporary perspectives on protein intake for athletes have moved beyond the population guidelines, typically set at $0.8-1.0 \mathrm{~g} / \mathrm{kg} \mathrm{BM}$ in most countries, both in 
terms of the total daily target as well as the advice around how it should be consumed over the day. Allowances which target the absence of protein insufficiency in largely sedentary populations do not address the needs of high performance triathletes who need to optimize the adaptive response to training and to achieve the physique attributes of lean mass to bodyfat ratio needed for successful performance in their events [26]. Dietary protein interacts with exercise, providing both a trigger and a substrate for the synthesis of contractile and metabolic proteins in the muscle [27, 28], as well as enhancing changes in non-muscle tissues such as tendons and bones. Planned intake of dietary protein can enhance the sustained $[\sim 24$ hour) increase in contraction-stimulated synthesis of muscle protein that occurs after strength or endurance exercise, by supplying leucine to further upregulate the mammalian target of rapamycin complex 1 (mTORC1) pathway $[27,28]$ as well as the amino acid building blocks for the synthesis of new proteins. High quality leucine-rich protein sources, when consumed in amounts equivalent to $\sim 0.3-0.4 \mathrm{~g} / \mathrm{kg}$ of rapidly digested protein at $4-5$ eating occasions per day, can optimize the training response when athletes are in optimal energy availability [18]. Meanwhile, a goal of $0.4-0.5 \mathrm{~g} / \mathrm{kg}$ might be required in scenarios of energy deficit/weight loss in which rates of muscle protein synthesis are suppressed [18] or in the case of mixed meals with slower protein digestion/absorption kinetics $[18,29]$. Overall daily targets of 1.3$1.7 \mathrm{~g} / \mathrm{kg} / \mathrm{d}$ are likely to meet the physique and adaptation goals of weight-stable triathletes. Meanwhile, triathletes who wish to achieve effective weight loss, which promotes the retention or even an increase in lean mass, are advised to engage in resistance exercise and to consume dietary protein in quantities of $1.6-2.4 \mathrm{~g} / \mathrm{kg}$ [18]. Table 1 includes a summary of the current recommendations for protein intakes for high performance athletes according to their major goals.

\section{Application to triathlon}


A high daily training commitment requires the triathlete to incorporate strategies that promote optimal performance in the current session while simultaneously facilitating recovery from the previous one. While heavy training loads accentuate this challenge for the elite competitor, recreational triathletes have the added complexity of managing their specific nutritional needs around other commitments such as work, family and study. Age-group triathletes typically 'sandwich' their training into concentrated weekend blocks often incorporating two or three disciplines into the one session (i.e. swim + cycle or cycle + run). This situation highlights the importance of athletes being well-planned to have suitable foods and fluids on hand, which cater to the practical considerations as well as their desire to eat.

The requirements for carbohydrate and protein on heavy training load days contrast with those of a sedentary work or rest days, necessitating vastly different eating patterns and food/fluid choices. For training sessions that reflect the demands of racing, additional carbohydrate intake can be achieved via pre-training snacks based on familiar and well tolerated carbohydrate-rich foods and fluids; in addition to increasing overall intake, this strategy specifically promotes high carbohydrate availability and performance benefits for these key sessions. As will be discussed in Theme 6, there are different benefits to undertaking lower intensity (aerobic) sessions with strategies that achieve low carbohydrate availability, such as training fasted or withholding carbohydrate early in a session. However, this strategy also decreases total daily nutrient/energy intake unless the triathlete can schedule additional snacks and/or increases in meal size to offset the energy reduction. Such dietary approaches should be incorporated with the assistance of expert dietary input from a skilled sports nutrition professional.

During extended training sessions (i.e. long training runs or cycling sessions or combination 'brick' sessions), there may be benefits to consuming food/fluid choices that provide protein to assist in the maintenance of positive protein balance and promotion of bone remodeling 
$[30,31]$ as well as carbohydrate for fuelling. When sessions are performed below race intensity, athletes typically have improved tolerance for wholesome, nutrient-rich foods. While these food options might not be suitable for racing, inclusion in training will support favourable adaptations to training while better supporting health and well-being.

\section{Theme 5. Competition nutrition strategies target the limiting factors in optimal performance}

Competition requires the athlete to perform at his or her best, or at least at a better level relative to other competitors. This goal rightly focusses attention to the factors that can cause fatigue at various timepoints throughout, and especially in the latter stages of a race, where fatigue is defined operationally as a loss of the work outputs (e.g. speed, power) and skill/technical prowess that otherwise underpin success. The causes of fatigue are specific to the race, the environment/scenario in which it is undertaken, and the individual athlete and include depletion of muscle glycogen fuel, dehydration and electrolyte imbalances, hypoglycemia and sub-optimal central nervous system fueling, gut discomfort/upset and disturbances to acid-base balance. Dietary practices in preparation for, and during a race can reduce or delay the onset of these fatigue factors.

\section{Application to triathlon}

With total race distances ranging from $20 \mathrm{~min}$ to $8+\mathrm{h}$ for top competitors, individual segments of each race ranging from 4 min to 4 hours, and environments scaling from cold water to extreme heat on bike and run courses, race nutrition in triathlon must tackle a variety of issues. Race preparation should include strategies to store muscle glycogen in the amounts that suit the fuel needs of the event. For shorter races (Olympic Distance and below), where the fuel cost is spread across different muscle groups, it is probably sufficient to normalize the superior glycogen concentrations associated with endurance training; this is typically achieved with $\mathrm{CHO}$ intakes of 7-10 g/kg body mass for $24 \mathrm{~h}$ [8]. For Long Distance/Half 
ironman and above, where glycogen may become limiting for race performance, protocols which supercompensate glycogen are beneficial. The contemporary $\mathrm{CHO}$ loading protocol is an abbreviated version of the original, involving 36-48 h of CHO intakes targeting 10-12 $\mathrm{g} / \mathrm{kg} / \mathrm{d}[8,32]$. This is often undertaken in conjunction with a low residue (fiber) diet, which may reduce the risk of gut issues during the race, but also achieve a small reduction in BM to partially offset the mass of the additional muscle glycogen and stored water [32]. Further enhancement of fuel availability is provided by a $\mathrm{CHO}$-rich pre-race meal and $\mathrm{CHO}$-rich snack during/after the race warm-up, noting that is impractical to consume further supplies during the swim leg of a race. Pre-race $\mathrm{CHO}$ intake is important for morning events where it can restore liver glycogen following an overnight fast as well as provide an ongoing supply of $\mathrm{CHO}$ from the gut during the first part of the race [32]. Event characteristics and individual preferences will dictate the amount, type and timing of pre-race intake; this should be well-practised to develop a personalized protocol. Athletes should also consider fluid needs to achieve optimal hydration status for the race and its specific environmental conditions.

Many triathlons offer an opportunity for athletes to consume fluid and $\mathrm{CHO}$ during the race to further address physiological limitations around these factors (Table 2). CHO ingestion during longer distance events (e.g. Long Distance and above) can maintain high rates of CHO oxidation in the face of dwindling endogenous stores [33], with a systematic review of studies of endurance protocols showing substantial benefits to performance [34]. Whereas older guidelines [6] recommended that distance athlete experiment with hourly $\mathrm{CHO}$ intakes within the range of 30-60 $\mathrm{g}$ to find a beneficial strategy, contemporary recommendations now suggest a sliding scale of intakes with smaller amounts for shorter duration events and higher rates of intake for longer distance and above [8]. These new guidelines are based on the mechanism of likely benefits to performance as well as the recognition that athletes can learn 
to tolerate and utilize substantially higher amounts than previously considered possible. Although the intestinal absorption of $\mathrm{CHO}$ consumed during exercise, plateauing at $\sim 60 \mathrm{~g} / \mathrm{h}$, was thought to limit the contribution of exogenous $\mathrm{CHO}$ to muscle fuel use during exercise [35], current advice is that intakes of $90 \mathrm{~g} / \mathrm{h}$ and even higher can be of benefit to very long races (e.g. Ironman). A combination of the use of mixtures of $\mathrm{CHO}$ using different absorption routes (e.g. fructose and glucose) and enhancement of gut tolerance and absorption $[35,36]$, possibly involving the upregulation of the sodium dependent glucose transporter (SGLT1), with chronic "gut training" [35] can increase the muscle CHO supply for better performance. However, even in shorter events in which muscle glycogen stores are not challenged, performance benefits may be associated with intake of smaller amounts of CHO. This is now known to be a central nervous system activation associated simply with mouth exposure to $\mathrm{CHO}$ (the so-called "mouth rinsing" effect). Indeed, there is robust evidence that the detection of $\mathrm{CHO}$ by receptors in the oral cavity activates centers in the brain which enhance perceptions of effort and pacing decisions [37]. Table 2 summarises the suggested approaches to $\mathrm{CHO}$ supply in various events, noting both the targets and the opportunities to achieve these during transitions, and the cycle and run legs. A range of sports drinks, gels, confectionery and whole foods can be used to meet various targets, both in training and racing, around taste, practicality, fluid vs $\mathrm{CHO}$ requirements, use of transportable $\mathrm{CHO}$ sources, electrolyte replacement, and supplementation with caffeine. Access to these supplies and the practicalities of consuming them vary according to the mode of exercise (e.g. the cycle leg is more accommodating than the run), the event organization (e.g. placement of feedzones) and race tactics.

Meanwhile, there is interest in nutritional strategies including chronic or periodized exposure to high fat, low $\mathrm{CHO}(\mathrm{LCHF})$ diets that may allow triathletes in ultra-endurance (Ironman and above) events to increase their ability to oxidize fat as a muscle fuel in view of its 
relatively unlimited pool size and capacity to support exercise at intensities up to $\sim 75-80 \%$

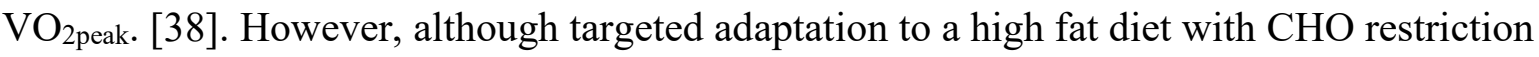
is associated with very high rates of fat utilization across a range of exercise intensities, this comes at a cost of a greater oxygen demand during exercise (lower speed for a given oxygen supply or greater oxygen requirement for the same speed) [39] as well as a down-regulation of the capacity of $\mathrm{CHO}$ oxidation pathways [40]. Such adaptations have been shown to impair performance of shorter endurance races [39], or selected segments within a longer race conducted at higher exercise intensities ( $>80-85 \%$ VO2peak) [41], probably limiting the utility of LCHF diets to selected individuals, events or scenarios [42]. Modelling of the total demands and rates of use of fat and $\mathrm{CHO}$ substrates in the Ironman event has created dissention about whether enhanced fat use would be sufficient to meet the needs of elite competitors [43-45]. Meanwhile, case histories have shown that periodization of $\mathrm{CHO}$ availability within a chronic LCHF diet might offer some performance advantages to some athletes and event characteristics [46], while chronic LCHF was unsuitable for performance of another elite Ironman competitor [47]. Further investigation is needed; however it is acknowledged that this is a polarising topic and any promotion of high fat diets needs to be balanced against evidence that higher rates of $\mathrm{CHO}$ intake during ironman racing is associated with faster performances [48].

Fluid intake to address sweat losses is important during longer events, especially those conducted in hot environments. Typically, a fluid deficit equivalent to $>2-3 \% \mathrm{BM}$ loss is considered to increase the perceived effort, raise core temperature, and cause reductions in performance, especially in the heat [49]. However, fluid intake should involve an individualized and well-practiced plan which balances the time cost of drinking, the risk of gut upsets and the potential advantages of being lighter, with the benefits of better hydration. Although sports drinks are commonly used to address fuel and fluid targets simultaneously, 
triathletes should consider their needs for carbohydrate and water replacement separately in different environmental conditions. For example, an increase in total fluid intake during Olympic distance triathlon races in hot weather will lead to a greater carbohydrate intake from such drinks [50]. While this outcome can address the slight increase in carbohydrate oxidation rates in hot conditions, higher carbohydrate intakes can also increase the risk of gastrointestinal upset [48]. A personalized drinking plan can be adjusted to all levels of triathlete, including recreational competitors who may drink in volumes exceeding their sweat rates and who should be warned about the dangers of developing hyponatremia [51]. Major triathlons are often held consistently (e.g. the Kona Ironman World Championships) or uniquely (e.g. Tokyo 2020 Olympic Games) in hot and/or humid environments. The performance and health challenges associated with hot weather racing should be addressed by strategies such as acclimatisation, appropriate pacing, and pre-cooling activities [52]. Nutrition practices include the adjustment of the race fluid plan including pre-race hyperhydration via consumption of large amounts of fluid together with an osmotic agent

(e.g. glycerol or sodium) to offset some of the in-race fluid deficit $[53,54]$. The integration of ice slurries within pre-cooling strategies to reduce pre-race core temperature via the "heat sink" created by the phase change from ice to water may also be beneficial [55]. All such practices should be well-trialled before implementing in a race.

\section{Theme 6. Nutrition for adaptation and recovery is a targeted tool}

A strenuous (prolonged and/or high intensity) session of exercise causes stress to the body including the depletion of body fuel stores, loss of fluids and electrolytes, inflammatory and redox responses, damage or increased breakdown of proteins, and disruption to homeostasis. Recovery between exercise sessions may have two separate but overlapping goals: restoration of body losses/changes caused by the first session to restore performance levels for the next and promotion of adaptive responses to the exercise stress to gradually enhance desirable 
body features/functions (see Fig 1). Over the past decade, post-exercise nutrition has been integrated into a highly promoted "recovery industry" that often targets athletes with onesize-fits-all strategies for universal application. While there is no doubt that such strategies are of benefit in many situations, particularly for scenarios involving multiple sessions of training each day, athletes should apply critical thinking to identify the importance of proactive recovery nutrition and the various issues involved (see Fig 1). The timing, amount and type of nutrient support provided after exercise should be determined by the specific conditions caused by the first session, the duration of the recovery period and the goals of the next session. Such attributes and goals of training are highly specific to the sport and individual athlete.

\section{Application to triathlon}

Although the scheduling of several training sessions in a day is a core feature of most high performance sports, triathlon poses a unique challenge in requiring the mastery of three disciplines and the need to practice the sequencing of these sports as they occur in a race. Needs around recovery and adaptation are of high importance to maximize the outcomes of the training load.

When restoration of function and performance is a priority, particularly around racing or key training sessions, it can often be useful to quickly supply nutrients without which some elements of recovery cannot happen effectively. For example, when it important to refuel between sessions, early intake of $\mathrm{CHO}$ (up to a threshold of $1 \mathrm{~g} / \mathrm{kg} / \mathrm{h}$ ) can maximize glycogen storage, including potentially taking advantage of a small period of enhanced synthesis in the hours after exercise [56]. Restoration of hydration status requires the replacement of the fluids and electrolytes lost in sweat; this often needs deliberate intake of sodium as well as a volume of fluid equivalent to $\sim 125 \%$ of the net fluid deficit to account for ongoing sweat and urine losses during the recovery period [57]. The specific case for post-exercise protein 
synthesis has been made previously (Theme 4) and the protein content of recovery meals/snacks can also be justified as a general contribution to the optimal distribution of protein intake over the day as well as an enhancer of glycogen synthesis when the $\mathrm{CHO}$ content of recovery eating is sub-optimal [58]. It is important to realise that not all postexercise situations call for such aggressive $\mathrm{CHO}$ and fluid intake strategies; indeed, in some situations this may lead to unnecessary intake of kilojoules, reliance on nutrient-poor choices or interrupted sleep due to overnight urination needs (see Table 1).

More importantly, there is growing recognition that the lack of nutrient support during and after exercise may accentuate the training stimulus and/or increase the adaptive response. Although there is interest in the concept that acclimatisation to exercise in hot weather may be enhanced by deliberately undertaking workouts with a moderate degree of dehydration [59], the principle of enhanced adaptation via altered nutrient availability is best demonstrated via the manipulation of muscle glycogen stores. Exercise undertaken with reduced $\mathrm{CHO}$ availability, particularly endogenous $\mathrm{CHO}$ stores, selectively modulates gene expression and intracellular signalling within the muscle. Mechanisms of these effects include alterations in cell osmolality and increased activity of molecules within the regulatory CHO-binding domain of the AMP-activated protein kinase, as well as perturbations to circulating FFAs and hormones in concert with plasma glucose and insulin concentrations [60]. A range of different strategies to augment the training response with low $\mathrm{CHO}$ availability ("train low") are available; these include commencing training with low exogenous $\mathrm{CHO}$ availability (e.g. overnight fasted and/or withholding $\mathrm{CHO}$ during a session), or the more potent strategy of deliberately commencing selected training sessions with lowered muscle glycogen stores (e.g. using a first session to deplete glycogen, then training for a second time after withholding $\mathrm{CHO}$ to prevent glycogen restoration $[21,58])$. 
Although there is clear evidence of enhanced cellular responses to train-low strategies, the translation to performance enhancement has been less certain. Early investigations failed to detect superior performance outcomes due to the impairment of training intensity when "train low" sessions were over-emphasised in the training program [61]. Such sessions need to be appropriately integrated into a periodized program to complement high-quality training. A recent sequencing of practices has been investigated: this involves a performance-promoting session ("train high" with high intensity), followed by restriction of CHO during recovery to prolong the post-exercise increase in cellular signalling and post-transcriptional regulation associated with depleted glycogen stores $[1,21]$. The next session of exercise is then undertaken as a moderate intensity "train low" session to complete the sequence [1]. In subelite populations of triathletes and cyclists, this better integration of train-low and train-high sessions into the training sequence has been associated with superior performance compared with the same training undertaken with normal CHO availability [62]. So far, however, this does not seem to be the case in studies involving elite endurance athletes [39,63], although it is often incorporated into real world training sessions [64].

A single bout of exercise causes immune, inflammatory and anti-oxidant responses, with chronic exercise (i.e. training) promoting adaptations in the systems involved. Unlike the situation with the previously discussed issues in post-exercise recovery, specific nutritional strategies to promote or preserve optimal anti-oxidant and immune function in athletes are not well described. It is beyond the scope of this chapter to fully interrogate our current understanding of the role of food-derived antioxidants or anti-inflammatory nutrients in recovery and performance. However, there is evidence that supplementation with large quantities of anti-oxidant supplements (e.g. Vitamin C and E) might interfere with adaptation via a dampening of the redox-related signalling processes associated with exercise [65], despite offering some advantages to the immediate recovery of oxidative status. There is also 
interest in foods containing high amounts of phenolic compounds with anti-inflammatory properties (e.g. various types of cherries and berries), particularly to reduce the post-exercise soreness and impaired muscle function often seen after strenuous sessions [66,67]. Although further investigation is needed to fully understand any benefits from these recovery nutrition strategies, it is generally suggested that food forms of phytochemicals might provide a more balanced approach to nutritional support and that approaches might be needed to address goals around immediate restoration of function versus longer-term adaptation.

\section{Theme 7. High performance athletes walk a tight-rope between adequate training stimulus and the risk of illness/injury}

Injuries and illness are a challenge to success in high performance sport and, ironically, athletes are potentially at higher risk of developing these as their caliber and training levels increase. Performance is likely to be directly affected if the athlete is sick and/or injured at the time of competition, but these issues can indirectly affect race outcomes by reducing the consistency of training. Injuries may occur to skeletal muscle, to bone, especially stress fractures, and to tendons and ligaments, especially in relation to high or constantly varying training loads, repetitive low impact modes of exercise (e.g. running) and to weaknesses in the tissues resulting from inadequate nutrient status or support. Given the high-prevalence and costs involved, it is not surprising that there has been a great deal of interest in factors that may reduce the injury risk, or decrease the recovery time should an injury occur. Bone stress fractures are frequently associated with LEA which should be corrected in both the prevention and treatment of such problems. Attention to Vitamin D status, and intake of protein and calcium should also be considered. Nutrition goals during injury rehabilitation include adjustment to new energy requirements and distribution of daily protein intake to minimize loss of lean mass and increase muscle repair [68]. The prevention and treatment of injuries to tendons and ligaments is an area of recent active research with initial data on the 
role of nutritional support from collagenous proteins and micronutrients (e.g. vitamin C, copper) showing some potential [69].

Physically demanding bouts of exercise reduce the metabolic capacity of immune cells, with this transient immunodepression lowering the resistance to pathogens and increasing the risk of subclinical and clinical infection and illness. This may be juxtaposed with an environment of high risk of exposure to pathogens, including travel to a location with different hygiene standards or just close encounters with other people as happens in training squads, long-haul flights, and group dining or living scenarios. Optimizing training load management (e.g. excessively large training volumes and/or sudden changes in training) and adequate sleep play a major role in reducing the incidence of illnesses, as do good hygiene practices around exposure to surfaces, food/water and people who may harbour pathogens. However, good nutrition status may also help to combat exercise-induced immunodepression, with important considerations including energy availability, and adequate intakes of protein, $\mathrm{CHO}$, fatty acids, and micronutrients (iron, zinc, magnesium, and Vitamins A and D). It is of interest that training with low $\mathrm{CHO}$ availability is associated with greater acute perturbations of cytokines that are important for immune status [23], iron metabolism [70, 71] and bone metabolism [24]. Although it is unclear whether chronically training under such scenarios or, by contrast, chronically using strategies that promote higher $\mathrm{CHO}$ availability during training, have an impact on long-term health and injury profiles, athletes who are already at higher risk of illness and injury should be aware of this finding.

Iron status is an important factor in health and performance, but compromised iron status is a common occurrence among endurance athletes, particularly females. This occurs due to factors from both exercise (e.g. hemolysis and alterations to the iron regulatory hormone hepcidin) and non-exercise origin (e.g. inadequate iron intake, heavy menstrual blood losses). 
Issues around iron status are covered in greater detail by Cairo (72). Routine screening of iron status according to standardized protocols and treatment of sub-optimal iron stores is recommended and should be incorporated into the annual training year, especially around travel and exposure to altitude. Options include dietary counselling to improve iron intake, oral iron supplements and, in the case where the athlete is unresponsive or where faster approaches are needed, an intramuscular or intravenous treatment under the supervision of a physician.

\section{Application to triathlon}

Triathletes face an increased risk of illness and injury from several characteristics: high and varying training loads across three different exercise disciplines, and regular racing programs both domestically and internationally. Consistent or lengthy interruptions to training will unravel the athlete's development, and either delay or derail their movement along the elite athlete pathway. The most common injuries experienced by elite triathletes relate to bone stress and require an extended rehabilitation period. It is important that nutrition plans incorporate strategies that optimize bone remodeling such as maintaining adequate energy availability, consuming adequate calcium, ensuring Vitamin D sufficiency and strategically planning $\mathrm{CHO}$ and protein intakes around daily training. While the daily training loads of recreational triathletes don't meet those of their elite athlete counterparts, the busy nature of daily triathlon training alongside work and family commitments can interfere with opportunities to incorporate adequate rest, recovery and sleep as well as incorporate appropriate food and fluid choices. Triathletes should be vigilant with their daily food and fluid choices to ensure they align with daily training requirements. Coaches and performance support staff play an important role to ensure athletes are reminded of the importance of incorporating appropriate nutrition strategies to support health and well-being.

\section{Theme 8. A pragmatic approach to supplements and sports foods is needed}


Athletes represent an enthusiastic audience for the numerous supplements and sports foods which make up a multi-billion dollar industry [73]. Of course, they also reflect the interests of the general community where the majority of people report supplement use. Although a "food first" philosophy is promoted in relation to nutritional needs, athletes often require medical supplements as part of a treatment or prevention plan for nutrient deficiencies; this includes iron deficiency [72] and Vitamin D deficiency [74]. In addition, sports foods may assist in meeting nutritional goals or nutrient targets in scenarios where it is impractical to eat whole foods. Meanwhile, the largest supplement categories with the most heavily marketed claims include performance products that directly enhance exercise capacity and supplements that provide indirect benefits through recovery, body composition management, and other goals. While the majority of these products are not supported by robust evidence, there are five (caffeine, creatine, nitrate/beetroot juice, beta-alanine and bicarbonate) which may contribute to performance gains, according to the event, the specific scenario of use and the individual athlete's response [75]. Specific challenges include developing protocols to manage repeated use of performance supplements in multiple events or training sessions in the same day, the interaction between several products that are used concurrently, and the individual experiences of athletes with regard to benefits and side-effects $[76,77]$.

Potential disadvantages of supplement use include expense, false expectancy, side effects and safety issues associated with poor manufacturing processes and the risk of ingesting substances banned under the World Anti-Doping Agency's List, which are sometimes present as contaminants or undeclared ingredients [78]. Strict liability codes mean that a positive urine test can trigger an Anti Doping Rule Violation with potentially serious impact on the athlete's career, livelihood and reputation, despite unintentional intake or minute (ineffective) doses. Despite earlier reluctance, many expert groups, including the International Olympic 
Committee [3] now pragmatically accept the use of supplements which pass a risk: benefit analysis of being safe, effective, legal, and appropriate to an athlete's age and maturation in their sport. Expert guidance or supervised use should be considered and all supplements should be trialed thoroughly by the individual before committing to using them in a competition setting. Third-party auditing of products can help elite athletes to make informed choices about supplement use but cannot provide an absolute guarantee of product safety [3].

\section{Application to triathlon}

Several supplements and supplement strategies are worthy of considered use across the various triathlon disciplines (Table 3). Sports foods provide an important aid in meeting high energy and nutrient needs, by providing a convenient and practical option for intake before, during and after training and races. Although triathletes rely heavily on fellow athletes, coaches and media outlets for information regarding supplement use, they should be directed to receive professional advice, particularly in the case of medical supplements.

Many triathletes are interested in the use of performance supplements on race day; indeed, caffeine is widely used in triathlon races [79]. However, even when such products can be justified, they should not take priority over the development and practice of fueling and hydration strategies. In fact, numerous sports foods and fluids contain caffeine, which should be accounted for in the race-day nutrition planning. Given the extended nature of several triathlon races and the delicate balance of consuming adequate $\mathrm{CHO}$ and fluid, the incorporation of performance supplements into a race nutrition plan should be well-rehearsed and carefully considered. Trialing the use of sports foods and fluids alongside performance supplements, within sessions that mimic race elements, should form a regular component of the training program. 


\section{References}

1. Burke LM, Hawley JA. Swifter, higher, stronger: What's on the menu? Science. 2018; 362[6416):781-787.

2. Thomas DT, Erdman KA, Burke LM. American College of Sports Medicine Joint Position Statement. Nutrition and Athletic Performance. Med Sci Sports Exerc. 2016;48[3):543-68.

3. Maughan RJ, Burke LM, Dvorak J, Larson-Meyer DE, Peeling P, Phillips SM, et al., IOC Consensus Statement: Dietary Supplements and the High-Performance Athlete. Int J Sport Nutr Exerc Metab. 2018; 28[2):104-125.

4. American College of Sports Medicine, Sawka MN, Burke LM, Eichner ER, Maughan RJ, Montain SJ, Stachenfeld NS. American College of Sports Medicine position stand. Exercise and fluid replacement. Med Sci Sports Exerc. 2007; 39(2):377-90

5. Mountjoy M, Sundgot-Borgen J, Burke L, Ackerman KE, Blauwet C, Constantini N, et al., International Olympic Committee (IOC) Consensus Statement on Relative Energy Deficiency in Sport (RED-S): 2018 Update. Int J Sport Nutr Exerc Metab. 2018; 28(4):316-331.

6. Coyle EF. Timing and method of increased carbohydrate intake to cope with heavy training, competition and recovery. J Sports Sci. 1991; 9 (Suppl); 29-51

7. Burke LM, Kiens B, Ivy JL. Carbohydrates and fat for training and recovery. J Sports Sci. $2004 ; 22(1): 15-30$

8. Burke LM, Hawley JA, Wong SH, Jeukendrup AE. Carbohydrates for training and competition. J Sports Sci. 2011;29 Suppl 1:S17-27.

9. Stellingwerff T, Morton JP, Burke LM. A framework for periodised nutrition for Athletics. Int J Sport Nutr Exerc Metab. 2019; epub ahead of print 
10. Sharma AP, Periard JD. Physiological requirements of the different distances of triathlon, in Triathlon Medicine XXXXX THIS BOOK

11. Loucks AB, Kiens B, Wright HH. Energy availability in athletes. J Sports Sci. 1991; 29 (Suppl 1): S7-15.

12. Loucks AB, Verdun M, Heath EM. Low energy availability, not stress of exercise, alters LH pulsatility in exercising women. J Appl Physiol. 1998;84(1):37-46.

13. Nattiv A, Loucks AB, Manore MM, Sanborn CF, Sundgot-Borgen J, Warren MP. American College of Sports Medicine position stand. The female athlete triad. Med Sci Sports Exerc. 2007;39(10):1867-82.

14. Burke LM, Close GL, Lundy B, Mooses M, Morton JP, Tenforde AS. Relative Energy Deficiency in Sport in Male Athletes: A Commentary on Its Presentation Among Selected Groups of Male Athletes. Int J Sport Nutr Exerc Metab. 2018; 28(4):364-374.

15. Ackland TR, Lohman TG, Sundgot-Borgen J, Maughan RJ, Meyer NL, Stewart AD, Müller W. Current status of body composition assessment in sport: review and position statement on behalf of the ad hoc research working group on body composition health and performance, under the auspices of the I.O.C. Medical Commission. Sports Med. 2012; 42(3):227-49.

16. Slater G., Shaw G., Kerr A. Athlete Considerations for Physique Measurement. In: Hume P., Kerr D., Ackland T. (eds) Best Practice Protocols for Physique Assessment in Sport. Springer, Singapore, 2018. pp 47-60.

17. Hector AJ, Phillips SM. Protein Recommendations for Weight Loss in Elite Athletes: A Focus on Body Composition and Performance. Int J Sport Nutr Exerc Metab. 2018; 28(2):170-177. 
18. Witard OC, Garthe I, Phillips SM. Dietary Protein for Training Adaptation and Body Composition Manipulation in Track and Field Athletes. Int J Sport Nutr Exerc Metab. 2019 Feb 25:1-10. Epub ahead of print

19. Stellingwerff T. Case Study: Body Composition Periodization in an Olympic-Level Female Middle-Distance Runner Over a 9-Year Career. Int J Sport Nutr Exerc Metab. $2018 ; 28(4): 428-433$

20. Hargreaves M, Spriet LL. Exercise Metabolism: Fuels for the Fire. Cold Spring Harb Perspect Med. 2018 Aug 1;8(8). pii: a029744

21. Burke LM, Hawley JA, Jeukendrup A, Morton JP, Stellingwerff T, Maughan RJ. Toward a Common Understanding of Diet-Exercise Strategies to Manipulate Fuel Availability for Training and Competition Preparation in Endurance Sport. Int J Sport Nutr Exerc Metab. 2018; 28(5):451-463

22. Stellingwerff T, Cox GR. Systematic review: Carbohydrate supplementation on exercise performance or capacity of varying durations. Appl Physiol Nutr Metab. 2014; 39(9):9981011

23. Peake JM, Neubauer O, Walsh NP, Simpson RJ. Recovery of the immune system after exercise. J Appl Physiol 2017;122(5):1077-1087.

24. Sale C, Varley I, Jones TW, James RM, Tang JC, Fraser WD, Greeves JP. Effect of carbohydrate feeding on the bone metabolic response to running. J Appl Physiol. 2015;119(7): 824-30.

25. Areta JL, Hopkins WG. Skeletal Muscle Glycogen Content at Rest and During Endurance Exercise in Humans: A Meta-Analysis. Sports Med. 2018;48(9):2091-2102.

26. Phillips SM, Chevalier S, Leidy HJ. Protein "requirements" beyond the RDA: implications for optimizing health. Appl Physiol Nutr Metab. 2016;41(5):565-72. 
27. Stokes T, Hector AJ, Morton RW, McGlory C, Phillips SM. Recent Perspectives Regarding the Role of Dietary Protein for the Promotion of Muscle Hypertrophy with Resistance Exercise Training. Nutrients 2018; 10:10.3390/nu10020180

28. Moore DR, Camera DM, Areta JL, Hawley JA, Beyond muscle hypertrophy: why dietary protein is important for endurance athletes. Appl Physiol Nutr Metab. 2014; 39: 987-997

29. McGlory C, van Vliet S, Stokes T, Mittendorfer B, Phillips SM.The impact of exercise and nutrition on the regulation of skeletal muscle mass. J Physiol. 2019 Mar;597(5):12511258.

30. Beelen M, Zorenc A, Pennings B, Senden JM, Kuipers H, van Loon LJ. Impact of protein coingestion on muscle protein synthesis during continuous endurance type exercise. Am J Physiol Endocrinol Metab. 2011;v300(6):E945-54.

31. Townsend R, Elliott-Sale KJ, Currell K, Tang J, Fraser WD, Sale C. The Effect of Postexercise Carbohydrate and Protein Ingestion on Bone Metabolism. Med Sci Sports Exerc. 2017; 49(6):1209-1218

32. Burke LM, Jeukendrup AE, Jones AM, Mooses M. Contemporary Nutrition Strategies to Optimize Performance in Distance Runners and Race Walkers. Int J Sport Nutr Exerc Metab. 2019 Apr 4:1-13 epub ahead of print

33. Coyle EF, Coggan AR, Hemmert MK, Ivy JL. Muscle glycogen utilisation during prolonged strenuous exercise when fed carbohydrate. J Appl Physiol. 1986;61:165-72.

34. Stellingwerff T, Cox GR. Systematic review: Carbohydrate supplementation on exercise performance or capacity of varying durations. Appl Physiol Nutr Metab. 2014:1-14.

35. Jeukendrup AE. Training the Gut for Athletes. Sports Med. 2017;47(Suppl 1):101-10.

36. Jeukendrup AE. Carbohydrate and exercise performance: the role of multiple transportable carbohydrates. Curr Opin Clin Nutr Metab Care. 2010; 13(4):452-7. 
37. Jeukendrup, A.E., \& Chambers, E.S. Oral carbohydrate sensing and exercise performance. Curr Opin Clin Nutr Metab Care 2010;13(4):447-51.

38. Volek JS, Noakes T, Phinney SD. Rethinking fat as a fuel for endurance exercise. Eur J Sport Sci. 2015;15(1):13-20.

39. Burke LM, Ross ML, Garvican-Lewis LA, Welvaert M, Heikura IA, Forbes SG, et al. Low carbohydrate, high fat diet impairs exercise economy and negates the performance benefit from intensified training in elite race walkers. J Appl Physiol. 2017;595(9):2785807.

40. Stellingwerff T, Spriet LL, Watt MJ, Kimber NE, Hargreaves M, Hawley JA, et al. Decreased PDH activation and glycogenolysis during exercise following fat adaptation with carbohydrate restoration. Am J Physiol Endo Metab. 2006;290(2):E380-8.

41. Havemann L, West S, Goedecke JH, McDonald IA, St-Clair Gibson A, Noakes TD, et al. Fat adaptation followed by carbohydrate-loading compromises high-intensity sprint performance. J Appl Physiol. 2006;100(1):194-202.

42. Burke LM. Re-Examining High-Fat Diets for Sports Performance: Did We Call the 'Nail in the Coffin' Too Soon? Sports Med. 2015;45 Suppl 1:S33-49.

43. Maunder E, Kilding AE, Plews DJ. Substrate Metabolism During Ironman Triathlon: Different Horses on the Same Courses. Sports Med. 2018. 48(10):2219-26.

44. Webster CC, Smith JA. Comment on: Substrate Metabolism During Ironman Triathlon: Different Horses on the Same Courses. Sports Med. 2018;48(10):2421-2.

45. Maunder E, Kilding AE, Plews DJ. Authors' Reply to Webster and Smith: Comment on: "Substrate Metabolism During Ironman Triathlon: Different Horses on the Same Courses". Sports Med. 2018;48(10):2423-4. 
46. Webster CC, Swart J, Noakes TD, Smith JA. A Carbohydrate Ingestion Intervention in an Elite Athlete Who Follows a LCHF Diet. Int J Sports Physiol Perform. 2017: 13(7):95760.

47. Mujika I. Case Study: Long-Term Low-Carbohydrate, High-Fat Diet Impairs Performance and Subjective Well-Being in a World-Class Vegetarian Long-Distance Triathlete. Int J Sport Nutr Exerc Metab. 2018 Nov 13:1-6. Epub ahead of print

48. Pfeiffer B, Stellingwerff T, Hodgson AB, Randell R, Pottgen K, Res P, et al. Nutritional intake and gastrointestinal problems during competitive endurance events. Med Sci Sports Exerc. 2012;44(2):344-51.

49. Sawka MN, Cheuvront SN, Kenefick RW. Hypohydration and Human Performance: Impact of Environment and Physiological Mechanisms. Sports Med. 2015;45 Suppl $1:$ S51-60.

50. Cox GR, Snow RJ, Burke LM. Race-day carbohydrate intakes of elite triathletes contesting olympic-distance triathlon events. Int J Sport Nutr Exerc Metab. 2010; 20(4):299-306

51. Hew-Butler T, Rosner MH, Fowkes-Godek S, Dugas JP, Hoffman MD, Lewis DP, et al. Statement of the Third International Exercise-Associated Hyponatremia Consensus Development Conference, Carlsbad, California, 2015. Clin J Sport Med. 2015;25(4):30320.

52. Racinais S, Alonso JM, Coutts AJ, Flouris AD, Girard O, Gonzalez-Alonso J, et al. Consensus recommendations on training and competing in the heat. Brit J Sports Med. 2015;49(18):1164-73.

53. Goulet EDB, Aubertin-Leheudre M, Plante GE, Dionne IJ. A meta-analysis of the effects of glycerol-induced hyperhydration on fluid retention and endurance performance. Int J Sport Nutr Exerc Metab. 2007;17(4):391-410 
54. Goulet EDB, De La Flore A, Savoie FA, Gosselin J. Salt + Glycerol-Induced Hyperhydration Enhances Fluid Retention More Than Salt- or Glycerol-Induced Hyperhydration. Int J Sport Nutr Exerc Metab. 2018; 28(3):246-252

55. Ross M, Abbiss C, Laursen P, Martin D, Burke L. Precooling methods and their effects on athletic performance : a systematic review and practical applications. Sports Med. 2013;43(3):207-25.

56. Burke LM, van Loon LJC, Hawley JA. Postexercise muscle glycogen resynthesis in humans. J Appl Physiol 2017;122(5):1055-67.

57. Maughan RJ, Shirreffs SM. Water Replacement before, during, and after Exercise: How Much Is Enough? Fluid Balance, Hydration, and Athletic Performance: CRC Press; 2015. p. $365-75$.

58. Betts JA, Williams C. Short-Term Recovery from Prolonged Exercise Exploring the Potential for Protein Ingestion to Accentuate the Benefits of Carbohydrate Supplements. Sports Med. 2010;40(11):941-59.

59. Garrett AT, Goosens NG, Rehrer NJ, Patterson MJ, Harrison J, Sammut I, et al. Shortterm heat acclimation is effective and may be enhanced rather than impaired by dehydration. Amer J Hum Biol. 2014;26(3):311-20.

60. Philp A, Hargreaves M, Baar K. More than a store: regulatory roles for glycogen in skeletal muscle adaptation to exercise. Am J Physiol Endo Metab. 2012;302(11):E134351.

61. Hearris MA, Hammond KM, Fell JM, Morton JP. Regulation of Muscle Glycogen Metabolism during Exercise: Implications for Endurance Performance and Training Adaptations. Nutrients. 2018;10(3). 
62. Marquet LA, Brisswalter J, Louis J, Tiollier E, Burke LM, Hawley JA, et al. Enhanced Endurance Performance by Periodization of Carbohydrate Intake: "Sleep Low" Strategy. Med Sci Sports Exerc. 2016;48(4):663-72.

63. Gejl KD, Thams LB, Hansen M, Rokkedal-Lausch T, Plomgaard P, Nybo L, et al. No Superior Adaptations to Carbohydrate Periodization in Elite Endurance Athletes. Med Sci Sports Exerc. 2017;49(12):2486-97.

64. Stellingwerff, T. (2012). Case study: nutrition and training periodization in three elite marathon runners. Int J Sport Nutr Exerc Metab 22(5): 392-400.

65. Gomez-Cabrera MC, Domenech E, Romagnoli M, Arduini A, Borras C, Pallardo FV, et al. Oral administration of vitamin $\mathrm{C}$ decreases muscle mitochondrial biogenesis and hampers training-induced adaptations in endurance performance. Am J Clin Nutr. 2008;87(1):142-9.

66. Bell PG, McHugh MP, Stevenson E, Howatson G. The role of cherries in exercise and health. Scand J Med Sci Sports. 2014 Jun;24(3):477-90.

67. Myburgh KH. Polyphenol supplementation: benefits for exercise performance or oxidative stress? Sports Med. 2014 May;44 Suppl 1:S57-70.

68. Burke L and Maughan R. Sports nutrition and therapy. Handbook of Sports Medicine and Science: Sports Therapy Services: Organization and Operations, International Olympic Committee. John Wiley \& Sons Ltd, London, 2012; 00 103-116

69. Shaw G, Lee-Barthel A, Ross ML, Wang B, Baar K.Vitamin C-enriched gelatin supplementation before intermittent activity augments collagensynthesis. Am J Clin Nutr. 2017;105(1):136-143.

70. McKay AKA, Peeling P, Pyne DB, Welvaert M, Tee N, Leckey JJ et al., Chronic Adherence to a Ketogenic Diet Modifies Iron Metabolism in Elite Athletes. Med Sci Sports Exerc. 2019;51(3):548-555 
71. Badenhorst CE, Dawson B, Cox GR, Laarakkers CM, Swinkels DW, Peeling P. Acute dietary carbohydrate manipulation and the subsequent inflammatory and hepcidin responses to exercise. Eur J Appl Physiol. 2015; 115(12):2521-30.

72. Cairo G. Endurance anaemia, relevance to triathlon. Triathlon Medicine THIS BOOK

73. Owens DJ, Allison R, Close GL. Vitamin D and the Athlete: Current Perspectives and New Challenges. Sports Med. 2018; 48(Suppl 1):3-16

74. Garthe I, Maughan RJ Athletes and Supplements: Prevalence and Perspectives. Int J Sport Nutr Exerc Metab. 2018; 28(2):126-138

75. Peeling P, Binnie MJ, Goods PSR, Sim M, Burke LM. Evidence-Based Supplements for the Enhancement of Athletic Performance. Int J Sport Nutr Exerc Metab. 2018; 28(2):178-187

76. Burke LM, Peeling P. Methodologies for Investigating Performance Changes With Supplement Use. Int J Sport Nutr Exerc Metab. 2018;28(2):159-169.

77. Burke LM. Practical Issues in Evidence-Based Use of Performance Supplements: Supplement Interactions, Repeated Use and Individual Responses. Sports Med. 2017; 47(Suppl 1):79-10

78. Martínez-Sanz JM, Sospedra I, Ortiz CM, Baladía E, Gil-Izquierdo A, Ortiz-Moncada R. Intended or Unintended Doping? A Review of the Presence of Doping Substances in Dietary Supplements Used in Sports. Nutrients. 2017; 9(10). pii: E1093.

79. Desbrow B, Leveritt M. Awareness and use of caffeine by athletes competing at the 2005 Ironman Triathlon World Championships. Int J Sport Nutr Exerc Metab. 2006;16(5):5455

80. AIS Sports Supplement Framework. www.sportaus.gov.au/ais/nutrition/supplements 
Fig 1 A representation of the various processes in recovery, integrating adaptation and restoration of function/homeostasis 
Table 1. Examples of the periodisation of nutrient intakes and dietary strategies for triathletes

\begin{tabular}{|c|c|c|c|}
\hline Nutrient/issue & Background & $\begin{array}{l}\text { Scenarios of training-cycle or daily } \\
\text { periodization }\end{array}$ & $\begin{array}{l}\text { Scenarios of within day } \\
\text { periodisation }\end{array}$ \\
\hline Energy & $\begin{array}{l}\text { Key determinants of energy needs } \\
\text { include body mass and the training } \\
\text { load. Energy intake may also need to } \\
\text { be manipulated to support growth, or } \\
\text { targeted changes in body composition }\end{array}$ & $\begin{array}{l}\text { Energy intake should be increased } \\
\text { on days of heavier training load, } \\
\text { or during phases of high volume } \\
\text { training }\end{array}$ & $\begin{array}{l}\text { It is likely that distributing energy over } \\
\text { the day to support training sessions will } \\
\text { lead to better metabolic outcomes than } \\
\text { irregular or concentrated (e.g. evening- } \\
\text { focussed) energy }\end{array}$ \\
\hline
\end{tabular}




\begin{tabular}{|c|c|c|c|}
\hline & $\begin{array}{l}\text { Consideration to the triathlete's } \\
\text { body composition should be given } \\
\text { when interpreting these guidelines }\end{array}$ & $\begin{array}{l}\text { to exercise or recover with low } \\
\text { CHO availability }\end{array}$ & $\begin{array}{l}\text { soon after the first session, targeting an } \\
\text { intake of } \sim 1 \mathrm{~g} / \mathrm{kg} / \mathrm{h} \text { until normal eating } \\
\text { patterns are resumed }\end{array}$ \\
\hline Protein & $\begin{array}{l}\text { Dietary protein intake interacts with } \\
\text { exercise to promote whole body } \\
\text { protein synthesis, including targeted } \\
\text { muscle proteins. Protein needs of } \\
\text { athletes in focused training are } \\
\text { greater than those of sedentary } \\
\text { people }\end{array}$ & $\begin{array}{l}\text { Triathletes in committed training } \\
\text { should aim for daily protein } \\
\text { targets of at least } 1.4-1.7 \mathrm{~g} / \mathrm{kg} \\
\text { Protein targets should be } \\
\text { increased to } 1.8-2.4 \mathrm{~g} / \mathrm{kg} / \mathrm{d} \text { to } \\
\text { preserve lean mass during periods } \\
\text { of active loss of body fat } / \text { mass }\end{array}$ & $\begin{array}{l}\text { Protein intake should be distributed over } \\
\text { the day at 3-5 meals } / \mathrm{snacks} \text {, each } \\
\text { providing at least } 0.3-0.4 \mathrm{~g} / \mathrm{kg} \mathrm{BM} \\
\text { When there is active promotion of lean } \\
\text { mass gain or adaptive response to } \\
\text { exercise, it may be useful to add a pre- } \\
\text { bed protein-rich snack } \\
\text { The target for each eating occasion } \\
\text { should be increased to } 0.4-0.5 \mathrm{~g} / \mathrm{kg} \text { in } \\
\text { scenarios of active fat } / \text { mass loss, or when } \\
\text { the meal is large and likely to have } \\
\text { delayed absorption }\end{array}$ \\
\hline
\end{tabular}




\begin{tabular}{|c|c|c|c|}
\hline & & & $\begin{array}{l}\text { ( } 125 \% \text { of the deficit) and electrolyte } \\
\text { losses may be useful in some situations } \\
\text { of recovery } \\
\text { It may be counter-productive to attempt } \\
\text { full rehydration after evening training } \\
\text { sessions if the need to urinate during the } \\
\text { night interferes with sleep }\end{array}$ \\
\hline Iron & $\begin{array}{l}\text { Iron requirements are increased in } \\
\text { athletes, particularly females and } \\
\text { endurance athletes to accommodate } \\
\text { increased iron losses and increased } \\
\text { needs for synthesis of new tissues } \\
\text { and iron-containing compounds. } \\
\text { Strenuous exercise interacts with the } \\
\text { iron regulating hormone, hepcidin, } \\
\text { to reduce iron absorption and } \\
\text { recycling }\end{array}$ & $\begin{array}{l}\text { - Iron requirements may be } \\
\text { increased during periods of high } \\
\text { training volume } \\
\text { - Iron status should be checked and } \\
\text { supported during periods of } \\
\text { altitude training to ensure that } \\
\text { erythropoetic responses are } \\
\text { optimised }\end{array}$ & $\begin{array}{l}\text { To maximise iron absorption, iron-rich } \\
\text { meals should be consumed at times in the } \\
\text { day that best avoid the interference } \\
\text { associated with post-exercise increases in } \\
\text { hepcidin }\end{array}$ \\
\hline Caffeine & $\begin{array}{l}\text { Caffeine enhances exercise capacity } \\
\text { and performance, especially to mask } \\
\text { fatigue and perception of effort. }\end{array}$ & $\begin{array}{l}\text { - Race day caffeine strategies } \\
\text { should be practiced in training to } \\
\text { identify successful protocols } \\
\text { - Caffeine intake may assist the } \\
\text { performance of fatiguing training } \\
\text { sessions, allowing the triathlete to } \\
\text { train harder; this may be most } \\
\text { useful for sessions involving } \\
\text { greater metabolic stress (e.g. } \\
\text { "train low") }\end{array}$ & $\begin{array}{l}\text { Daily rituals of "social" intake of } \\
\text { caffeine may be organised to contribute } \\
\text { to performance uses of caffeine } \\
\text { - Caffeine intake over the day should be } \\
\text { organised to avoid negative effects on } \\
\text { sleep }\end{array}$ \\
\hline
\end{tabular}


Table 2. Nutritional strategies for high performance athletes in key triathlon races

\begin{tabular}{|c|c|c|c|c|c|}
\hline $\begin{array}{l}\text { Event and typical finish times of } \\
\text { competitive triathletes }\end{array}$ & $\begin{array}{l}\text { Mixed relay } \\
(\sim 20-25 \text { min })\end{array}$ & $\begin{array}{l}\text { Sprint } \\
(\sim 55-75 \mathrm{~min})\end{array}$ & $\begin{array}{l}\text { Olympic } \\
(1: 45-2: 15 \text { h:min })\end{array}$ & $\begin{array}{l}\text { Half Ironman } \\
(3: 30-4: 30 \text { h:min })\end{array}$ & $\begin{array}{l}\text { Ironman } \\
(8: 00-10: 00)\end{array}$ \\
\hline $\begin{array}{l}\text { Pre-race refueling: } \\
\text { - } \quad \text { Normalization of glycogen = } \\
7-12 \mathrm{~g} / \mathrm{kg} / \mathrm{d} \text { for } 24 \mathrm{~h} \\
\text { - } \mathrm{CHO} \text { loading }=10-12 \mathrm{~g} / \mathrm{kg} / \mathrm{d} \\
\text { for } 36-48 \mathrm{~h}\end{array}$ & $\begin{array}{l}\text { Glycogen } \\
\text { normalization }\end{array}$ & $\begin{array}{l}\text { Glycogen } \\
\text { normalization }\end{array}$ & $\begin{array}{l}\text { Glycogen } \\
\text { normalization }\end{array}$ & $\begin{array}{l}\text { CHO loading, while } \\
\text { maintaining typical } \\
\text { fibre intake }\end{array}$ & $\begin{array}{l}\text { CHO loading, } \\
\text { especially with low } \\
\text { residue diet }\end{array}$ \\
\hline $\begin{array}{l}\text { Opportunities for in-race } \\
\text { nutrition: } \\
\text { Includes race feed zones and } \\
\text { participant's own supplies }\end{array}$ & Nil - not needed & & $\begin{array}{l}\text { Transition areas } \\
\text { Participants can } \\
\text { carry bike- } \\
\text { mounted bottles } \\
\text { and sports foods }\end{array}$ & $\begin{array}{l}\text { Transition areas } \\
\text { Participants can carry } \\
\text { bike-mounted bottles } \\
\text { and sports foods } \\
\text { Feed zones are } \\
\text { provided on bike and } \\
\text { run course }\end{array}$ & $\begin{array}{l}\text { Transition areas } \\
\text { Participants can carry } \\
\text { bike-mounted bottles } \\
\text { and sports foods } \\
\text { Feed zones are } \\
\text { provided on bike and } \\
\text { run course }\end{array}$ \\
\hline $\begin{array}{l}\text { In race fuelling goals } \\
\text { - } 45-75 \text { min: mouth rinse/small } \\
\text { CHO amount } \\
\text { - } 1-2.5 \mathrm{~h}: 30-60 \mathrm{~g} / \mathrm{h} \\
\text { - } \quad>2.5 \mathrm{~h}: \text { up to } 90 \mathrm{~g} / \mathrm{h}\end{array}$ & N/A & N/A & $\begin{array}{l}\text { Trial CHO mouth } \\
\text { rinse up to intake } \\
\text { of } 30-60 \mathrm{~g} \text { from } \\
\mathrm{CHO}-\mathrm{drinks} \text { or } \\
\text { gels/ } \\
\text { confectionery }\end{array}$ & $\begin{array}{l}30-60 \mathrm{~g} / \mathrm{h} \mathrm{CHO} \text {; } \\
\text { Consider trialling } \\
\text { intakes up to } 90 \mathrm{~g} / \mathrm{h} \\
\text { using } \mathrm{CHO}-\text { drinks } \\
\text { and concentrated } \\
\text { gels/ confectionery }\end{array}$ & $\begin{array}{l}\text { Target intakes up to } \\
90 \mathrm{~g} / \mathrm{h} \text { using CHO- } \\
\text { drinks, gels/ } \\
\text { confectionery and } \\
\text { real foods on bike. } \\
\text { Run leg may have } \\
\text { fewer practical }\end{array}$ \\
\hline
\end{tabular}




\begin{tabular}{|c|c|c|c|c|c|}
\hline & & & & & $\begin{array}{l}\text { choices and need } \\
\text { lower targets. }\end{array}$ \\
\hline $\begin{array}{l}\text { In race hydration goals } \\
\text { - Aim to keep net fluid deficit }< \\
2-3 \% \mathrm{BM} \text {, especially in hot } \\
\text { weather }\end{array}$ & $\mathrm{N} / \mathrm{A}$ & $\mathrm{N} / \mathrm{A}$ & $\begin{array}{l}\text { Cost: benefit } \\
\text { analysis may show } \\
\text { that time cost of } \\
\text { drinking larger } \\
\text { volumes may } \\
\text { negate benefits in } \\
\text { elite triathletes }\end{array}$ & $\begin{array}{l}\text { Plentiful } \\
\text { opportunities for } \\
\text { frequent small } \\
\text { intakes of CHO- } \\
\text { drinks towards race } \\
\text { fluid plan }\end{array}$ & $\begin{array}{l}\text { Plentiful } \\
\text { opportunities for } \\
\text { frequent small } \\
\text { intakes of CHO- } \\
\text { drinks towards race } \\
\text { fluid plan }\end{array}$ \\
\hline \multirow{3}{*}{$\begin{array}{l}\text { Special issues for hot weather } \\
\text { events } \\
\text { Pre-cooling and hyperhydration } \\
\text { may be added to more aggressive } \\
\text { fluid plans }\end{array}$} & \multirow{2}{*}{\multicolumn{2}{|c|}{$\begin{array}{l}\text { Consider pre-race pre-cooling with ice } \\
\text { slurry in addition to external cooling } \\
\text { strategies if significant thermal } \\
\text { challenge is anticipated. }\end{array}$}} & \multicolumn{3}{|c|}{$\begin{array}{l}\text { Consider pre-race pre-cooling with ice } \\
\text { slurry in addition to external cooling } \\
\text { strategies if significant thermal challenge } \\
\text { is anticipated. }\end{array}$} \\
\hline & & & $\begin{array}{l}\text { Consider pre-race } h \\
\text { fluid deficit is antic }\end{array}$ & $\begin{array}{l}\text { lyperhydration if large } \\
\text { ipated. }\end{array}$ & \\
\hline & & \multicolumn{4}{|c|}{$\begin{array}{l}\text { Where possible, adjust fluid intake during event, independently of carbohydrate } \\
\text { intake, in view of increased sweat losses }\end{array}$} \\
\hline $\begin{array}{l}\text { Special comments for non-elite } \\
\text { competitors }\end{array}$ & \multicolumn{5}{|c|}{ Do not overdrink by consuming fluid in excess of sweat losses } \\
\hline
\end{tabular}


Table 3 Supplements and sports foods of potential value to triathletes and triathlon performance [80]

\begin{tabular}{|c|c|c|}
\hline Type & Product & Characteristics and evidence-based uses \\
\hline \multirow[t]{5}{*}{ Sports foods } & Sport drinks & $\begin{array}{l}\text { - CHO-containing fluid (typically } 6-8 \% \text { concentration) which supports fuelling and hydration goals } \\
\text { during and after workouts and races. } \\
\text { - Provides moderate levels of key electrolytes (e.g. } \sim 20 \mathrm{mmol} / \mathrm{L} \text { sodium) to help replace sweat } \\
\text { electrolyte losses and increase voluntary intake of fluid. }\end{array}$ \\
\hline & $\begin{array}{l}\text { Sport gels and } \\
\text { confectionary }\end{array}$ & $\begin{array}{l}\text { - Convenient and compact CHO source to assist with fuelling goals during workouts and races. } \\
\text { - May contain multiple transportable CHO sources to aid intestinal absorption when intakes }>60 \mathrm{~g} / \mathrm{h}\end{array}$ \\
\hline & $\begin{array}{l}\text { Liquid meal } \\
\text { supplements }\end{array}$ & $\begin{array}{l}\text { - Convenient, portable, and easy-to-consume source of carbohydrate, protein, and micronutrients } \\
\text { - Situations of use include as a well-tolerated pre-event meal or post-exercise recovery snack, or } \\
\text { during travel when access to food is limited }\end{array}$ \\
\hline & $\begin{array}{l}\text { Protein } \\
\text { supplements }\end{array}$ & $\begin{array}{l}\text { - Concentrated protein from high-quality foods (e.g. milk) or isolated protein fractions (e.g. whey) } \\
\text { - Provides convenient option to meet protein intake target when it is impractical to transport, prepare } \\
\text { or consume food sources of protein [e.g. immediately post-exercise, during travel). }\end{array}$ \\
\hline & $\begin{array}{l}\text { Electrolyte } \\
\text { supplements }\end{array}$ & $\begin{array}{l}\text { - Provides larger concentrations of electrolytes (e.g. } \sim 50 \mathrm{mmol} / \mathrm{L} \text { sodium) for more targeted } \\
\text { replacement } \\
\text { - Situations of use include pre-exercise hyperhydration before races in hot conditions, pro-active } \\
\text { electrolyte replacement in long races by individuals with large sweat/sodium losses, and assisted } \\
\text { rehydration following moderate to severe dehydration/electrolyte loss. }\end{array}$ \\
\hline \multirow[t]{3}{*}{$\begin{array}{l}\text { Medical } \\
\text { supplements }\end{array}$} & $\begin{array}{l}\text { Iron } \\
\text { supplements }\end{array}$ & $\begin{array}{l}\text { - Supplemental form of iron for prevention and treatment of diagnosed cases of reduced iron } \\
\text { deficiency. Should be taken under the supervision of a medical practitioner and sports dietitian and } \\
\text { in conjunction with dietary intervention. }\end{array}$ \\
\hline & $\begin{array}{l}\text { Calcium } \\
\text { supplements }\end{array}$ & $\begin{array}{l}\text { - Supplemental form of calcium for prevention and treatment of poor bone status when diet is unable } \\
\text { to meet calcium requirements. Should be taken under the supervision of a medial practitioner and } \\
\text { sports dietitian and in conjunction with appropriate medical and dietary intervention (e.g. to address } \\
\text { low energy availability) }\end{array}$ \\
\hline & $\begin{array}{l}\text { Vitamin D } \\
\text { supplements }\end{array}$ & $\begin{array}{l}\text { - Supplemental form of Vitamin D for prevention and treatment of Vitamin D } \\
\text { insufficiency/deficiency due to inadequate sunlight exposure. Should be taken under the supervision } \\
\text { of a medical practitioner }\end{array}$ \\
\hline
\end{tabular}




\begin{tabular}{|c|c|c|}
\hline \multirow[t]{4}{*}{$\begin{array}{l}\text { Performance } \\
\text { supplement }\end{array}$} & $\begin{array}{l}\text { Glycerol for } \\
\text { hyperhydration }\end{array}$ & $\begin{array}{l}\text { - Total body water may be increased when glycerol is consumed }(1-1.2 \mathrm{mg} / \mathrm{kg}) \text { as an osmotic agent } \\
\text { with a large bolus of fluid [ } 20-25 \mathrm{ml} / \mathrm{kg} \text { ) in the hours before a race } \\
\text { - Hyperhydration strategies might be useful to reduce overall fluid deficit in races undertaken in the } \\
\text { heat in which large sweat losses cannot be practically replaced during the event } \\
\text { - Should be undertaken under the supervision of a sport scientist and with appropriate } \\
\text { experimentation during training. }\end{array}$ \\
\hline & Caffeine & $\begin{array}{l}\text { - Highly biologically active compound with many effects including masking of pain/fatigue/perceived } \\
\text { effort, and enhanced recruitment of muscle motor units } \\
\text { - Small to moderate doses ( } \sim 3 \mathrm{mg} / \mathrm{kg} \mathrm{BM}) \text { appear to be as effective as larger doses }[5-6 \mathrm{mg} / \mathrm{kg} \mathrm{BM}) \text { in } \\
\text { enhancing the performance of races of } 1 \text { hour and greater } \\
\text { - Further studies should investigate the range of triathlon events that benefit from caffeine intake and } \\
\text { various effective doses and consumption protocols (e.g., intake before, during, or toward the end) } \\
\text { - May be consumed in cola, energy drinks, sport gels/confectionary, tablets and gum. There are } \\
\text { problems with using coffee as a source of caffeine due to the variability of the caffeine dose }\end{array}$ \\
\hline & $\begin{array}{l}\text { Nitrate } \\
\text { (beetroot juice) }\end{array}$ & $\begin{array}{l}\text { - Inorganic nitrate works with enterosalivary system to produce Nitric Oxide through an alternative } \\
\text { and oxygen-independent pathway to arginine-NO production } \\
\text { - Associated with improved exercise economy (reduction in oxygen cost of submaximal exercise) to } \\
\text { improve endurance exercise performance, and enhanced skeletal muscle contractile function to } \\
\text { improve muscle power and sprint exercise performance } \\
\text { - Typical dose }=\sim 8 \mathrm{mmol} \text { nitrate taken } 2-3 \mathrm{~h} \text { pre-race, especially with chronic intake for } 3+\mathrm{d} \text { pre- } \\
\text { trial, but intake during longer races may sustain the effect } \\
\text { - Effect of nitrate supplementation on endurance events is inconsistent and may involve individual } \\
\text { responsiveness, including observations that it seems less effective in elite athletes }\end{array}$ \\
\hline & $\begin{array}{l}\text { B-alanine } \\
\text { [chronic) } \\
\text { supplementation }\end{array}$ & $\begin{array}{l}\text { - There is potential, but inconsistent evidence, that an increase in blood-buffering capacity might } \\
\text { enhance the performance of short higher-intensity races of up to } 30-60 \mathrm{~min} \text { duration [e.g., relays, } \\
\text { sprint triathlons) where disturbances to acid-base balance occur due to reliance on oxygen- } \\
\text { independent glycolytic pathways of ATP production. } \\
\text { - Acute increases in extra-cellular buffering may be achieved by consuming } 300 \mathrm{mg} / \mathrm{kg} \mathrm{BM} \\
\text { bicarbonate, } 2 \text { hr pre-race. Further field studies are needed with high-level triathletes to confirm } \\
\text { benefits. Risk of gastrointestinal problems should be noted, especially in combination with high- } \\
\text { intensity running }\end{array}$ \\
\hline
\end{tabular}




\begin{tabular}{|l|}
\hline - Increased intra-cellular buffering may be achieved by increases in muscle carnosine content via \\
chronic supplementation with B-alanine (e.g. 6-10 w @ 3-6 g/d). Split doses over the day or \\
sustained release preparations may reduce the common side-effects of paraesthesia (tingling).
\end{tabular}




\section{Exercise $=$ stress + stimulus}

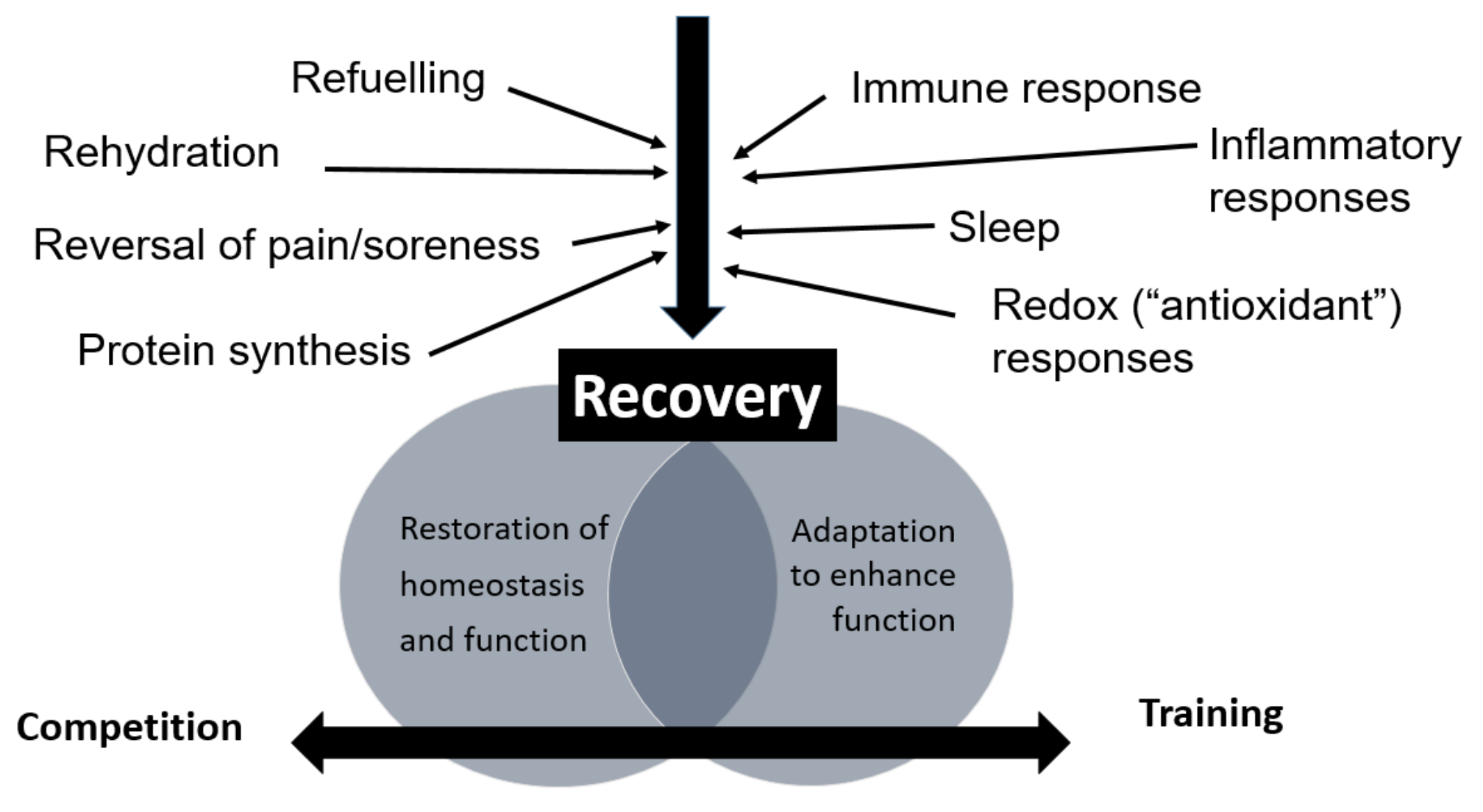

